\title{
The Administrative Strategy of the Islamic State by the Righteous Caliphs Decrees: Case Study on the Decree of Ali bin Abi Talib to the Ruler of Egypt
}

\author{
Dr. Ghassan Mahmoud Wishah* \\ Head of History and Archeology Department in the Islamic University of Gaza, Palestine
}

*Corresponding Author: Dr. Ghassan Mahmoud Wishah, Head of History and Archeology Department in the Islamic University of Gaza, Palestine

\begin{abstract}
This study used the comparative analysis approach to investigate an Islamic document with political, social, administrative and economic dimensions in ruling the Islamic state. It is a decree from the Emir of the believers, Ali bin Abi Talib (may Allah be pleased with him), to the Ruler of Egypt, in his era, Malik al-Ashtar. The study analyzed the texts of the document, showed its significance and promoted it with verses from the Holy Quran, Sunnah and views of Islamic scholars. The introduction mentioned the general definition of the document, while the first section included the political implications in that era. It talked about the foreign policy of the Islamic State in which the first part discussed the protection of the Islamic State and the principles of covenants with the enemies. The second part talked about the internal policy of the Islamic ruler including kindness and good treatment with the people of the state, guaranteeing human rights, adopting administrative strategy based on choosing the honest entourage of ministers, common people agreement is more important than the agreement of the chiefs, the principle of shura (advisory) and adopt the model of separation of powers. In addition, the second section dealt with the Islamic State attitude through the decree of the CaliphAli bin Abi Talib. The first part listed the foundations of economic development according to the covenant; cultivation is more important than Kharaj (land tax) and the organization of trade. The second part of the section included human rights during the era of the Caliph Ali may Allah be pleased with him.
\end{abstract}

\section{INTRODUCTION}

The decree of Ali bin Abi Talibto the Ruler of Egypt Malik aL-Ashter ${ }^{1}$ is a document which has political, social and legal dimensions. It included the concepts of ruling and treating people, the basis of relationship between the ruler and the people. This document considered the principle of comprehensiveness in theorizing citizen rights in the Islamic State in which it preceded many provisions in this field by using the characteristics of Islam in ruling and the rights and duties of citizens.

In this decree, the Caliph Ali bin Abi Talib introduced the Islamic theory on how to run and rule the country, depending on the four Islamic rules; freedom, equality, justice and Shura. This covenant contained about 94 items that showed the foundations of the covenant such as the duties of the ruler to protect citizen rights, the concept of majority in the Islamic perspective, the rights of traders, manufacturers and investors, the rights of poor people and the right to comply with peace treaties ${ }^{2}$ which are equal to the current rules ${ }^{3}$.

The document, based on the Islamic religion principles, showed the Islamic point of view in ruling, how the Caliph of Muslims run the Islamic State in that time, its strategy based on justice, shura, respect of human rights and select the best to run the state and regulate the relation between the ruler and the people.

\footnotetext{
${ }^{1}$ Malik al-Ashtar ibn al-Harith ibn Abi Yaguth bin Muslimah, was in Isfahan in the era of Ali bin Abi Talib, Umirr bin Saedsaid: a group of people and I visited al-Ashtar in Isfahan. He was poisoned and died by Qalzam in the year of 37in (2/291). Ali al-Ashtar was the Ruler of Egypt until he reached Qalqaz, drank little honey, the Great History of Bukhari (7/311).

${ }^{2}$ Wishah, Ghassan, Human Right in the Islamic State (198).

${ }^{3}$ Jawad, the Old Right (28).
} 
The Administrative Strategy of the Islamic State by the Righteous Caliphs Decrees: Case Study on the Decree of Ali bin Abi Talib to the Ruler of Egypt

\subsection{Importance of the Study}

- Spot the light on the Islamic document of political, economic and administrative dimensions.

- Examine models of Islamic documents related to administrative and international policies.

- Highlight the attitude of the Islamic State of human rights in the era of the Caliph Ali bin Abi Talib.

- Indicate the primacy of the Islam in guaranteeing the principles of human rights.

- Show the Islamic strategy in ruling the state internally and externally in the era of the Caliph Ali bin Abi Talib.

\subsection{Purposes of the study}

- Show the state attitude of human rights.

- Recognize the Islamic strategy in ruling the state.

- Demonstrate the aspects of economic development in the Islamic State in the Caliph era.

- Reveal the practical usage of Islamic Sharia by the Caliphs.

\section{MeThodology}

The study used the comparative analysis approach.

\subsection{Limitations of the Study}

The temporal limit: the period of the righteous caliphate of Ali bin Abi Talib, May Allah be pleased with him from $35 \mathrm{AH}$ to $40 \mathrm{AH}$.

Spatial Limit: State in the Rashidi era.

\subsection{Sections of the Study}

The study has two sections; the first section discussed the political implications included in the decree of Caliph Ali bin Abi Talib sent to Malik al-Ashtar. The second section talked the foundations of managing the Islamic State in the era of Ali bin Abi Talib. It is divided to two parts; the economic development and the implications of human rights in the Islamic State as mentioned in the document.

\subsection{Definition of the Covenant from Ali Bin Abi Talib to the Ruler of Egypt}

It was a letter with administrative dimensions sent by Ali bin Abi Talib to the Ruler of Egypt Malik al-Ashtar ${ }^{4}$ when he took over the caliphate in $35 \mathrm{AH}^{5}$. It contained many legal, administrative and political recommendations to the Ruler of Egypt. In the beginning of the covenant, the Caliph stated, "collect the jibaya (tax), fight against the enemy, seek the good of its people and make its cities prosperous" development and social development.

The legislative, political, administrative, judicial, financial, rules constitutional theories approved by the Caliph Ali, during the time of Malik al-Ashetar were clear examples of the democratic ruling in Islam compared to the current democratic or dictator ruling regimes and the legal theories prevailing in the civilized world. ${ }^{7}$

The covenant included nearly 94 items divided to 35 paragraph $^{8}$ about the strategy of the Islamic ruling, started from the responsibilities of the ruler to the rights and duties of the citizen. For example, it clarified the relation between the ruler and the people and social categories, economic, social development and the internal and external policy of the state. This covenant characterized by the fact that it was before the current implemented covenants.

\footnotetext{
${ }^{4}$ Bin Hamdoun, Atazkara Al-Hamdunia (1/316): Al-Nuwairi, Nihayat al-Arb fi Fnoun al-Adab (6/20).

${ }^{5}$ Ibn Kathir, al-BidayahwlNihayah (7/249).

${ }^{6}$ Atazkara Al-Hamdunia (1/316): Al-Nuwairi, Nihayat al-Arb fi Fnoun al-Adab (6/20).

${ }^{7}$ Vekiki, the Ruler and people (p. 16).

${ }^{8}$ Atazkara Al-Hamdunia (1/316): Al-Nuwairi, Nihayat al-Arb fi Fnoun al-Adab (6/20).
} 


\section{Section1: The Political Implications of The Covenant}

\section{First: the foreign policy}

The protection of the state

The Emir recommended Malik bin Hareth al-Ashtar during his rulingon Egypt to fight against the enemy, seek the good of its people, and make its cities prosperous. He ordered him to fear Allah and prefer obedience to $\mathrm{Him}^{9}$. The foreign policy of the Caliph focused on facing the danger of the enemies who threatening the Islamic State by confronting them and protect the citizens in response to what Allah said in the Holy Quran," O ye who believe! Fight the unbelievers who gird you about, and let them find firmness in you: and know that Allah is with those who fear Him." ${ }^{10}$

The defense of the Islamic State comes under the item of Jihad, "Repelling the aggressor is the hardest kind of fight because the aggressor corrupts the religion and world, nothing is important after faith than this unconditioned repel yet to do it as much as possible ${ }^{11}$.

Islam does not deviate from this normal situation unless an enemy start aggression, do harm and abuse people, then Muslims become authorized to resist the aggression to achieve peace and justice, as they are not allowed to be aggressive. ${ }^{12}$

\subsection{Commitment to the Covenant with the Enemy}

As there is time of war, there is time of peace. Making treaties with the enemies impose you to commit to them. He wrote, "If you conclude an agreement between yourself and your enemy or enter into a pledge with him then fulfil your agreement and discharge your pledge faithfully. Place yourself as a shield against whatever you have pledged because among the obligations of Allah there is nothing on which people are more strongly united despite the difference of their ideas and variation of their views than respect for fulfilling pledges. Besides Muslims, even unbelievers have abided by agreements because they realized the dangers which would come in the wake of violation (thereof). Therefore, do not deceive your enemy, because no one can offend Allah save the ignorant and the wicked. Allah made His agreement and pledged the sign of security which He has spread over His creatures." ${ }^{13}$ The Caliph urged to commit to the treaties with the enemies and the people of Dimmah (non-Muslims living in an Islamic state with legal protection)as Allah stated, " But if the enemy incline towards peace, do thou (also) incline towards peace, and trust in Allah: for He is One that heareth and knoweth (all things)." ${ }^{14}$ If they tend to peace (inclined to your religion) by converting to Islam, paying the tribute, making truce or other reasons of peace and reconciliation, you should incline towards peace with them and exert the effort to achieve that. ${ }^{15}$

Allah said," So fulfil your engagements with them to the end of their term, for Allah love the righteous." ${ }^{16}$ Keep your covenant with them and do not start a war until the end of covenant ${ }^{17}$. Allah will ask each Muslim about their commitment to the covenants because it is a religious duty in which any violation considered a treachery. ${ }^{18}$

\section{Second, the internal policy}

The internal policy in the Islamic State characterized in accordance with the perspective of the Caliph basing in the following:

- Follow the policy of kindness and good treatment with the state's citizens.

- Guarantee the rights and the common people agreement is more important than the agreement of the chiefs.

\footnotetext{
${ }^{9}$ Bin Hamdoun, ,Atazkara Al-Hamdunia (1/316).

${ }^{10}$ Surah Al-Tawbah, verse (123).

${ }^{11}$ Ibn Taymiyah, Great Fatwas.

${ }^{12}$ Shaltout, Islam is a Doctrine and Sharia (p. 455).

${ }^{13}$ Bin Hamdoun, Atazkara Al-Hamdunia (1/326): Al-Nuwairi, Nihayat al-Arb fi Fnoun al-Adab (6/19).

14 Al-Anfal, verse (4).

${ }^{15}$ Tafseer al-Tabari (14/40).

${ }^{16}$ Surah Al-Tawbah (4).

${ }^{17}$ Tafseer al-Tabari (14/132).

${ }^{18}$ Shaltout, Islam is a Doctrine and Sharia (p. 457).
} 
The Administrative Strategy of the Islamic State by the Righteous Caliphs Decrees: Case Study on the Decree of Ali bin Abi Talib to the Ruler of Egypt

- Choose the honest entourage of ministers and state employees carefully.

- Apply the principle of shura.

- Adopt the policy of separation of powers.

\subsection{Follow the Policy of Kindness and Good Treatment with the State's Citizens}

In his internal policy, the Caliph asserted on treating citizens in good and kind way as the head of policy is kindness ${ }^{19}$ as it is said "who want to do justice to people do it by himself." 20

The covenant made for Egypt ruling contained provisions and instructions for the ruler to treat citizens kindly and mercifully, "people's love manifests itself only when their hearts are $\operatorname{clean}^{21} \ldots$ you should work to ease and repair their positions without boredom by you."

\subsection{Guarantee the Rights and the People Agreement is Over the Chiefs' Agreement}

There is no discrimination in Islam since all people are equal as Muhammad (pbuh) said, "O people, your Lord is one and your father Adam is one. There is no favor of an Arab over a foreigner, nor a foreigner over an Arab, and neither white skin over black skin, nor black skin over white skin, except by righteousness." 22

However, all states distribute jobs between two classes, chiefs of political positions, which represents ruler entourage, and the common class, which represents the other society members such as traders, manufacturers, and other professionals who do not detract from their rights or values in the Islamic State. Therefore, the Caliph recommended the Ruler of Egypt to pay more attention to satisfy the common people class over the chief class.

"The way most coveted by you should be that which is the most equitable for the right, the most universal by way of justice, and the most comprehensive with regard to the agreement among those under you, because the disagreement of the common people sweeps away the arguments of the chiefs. Yet the disagreement of the chiefs can be disregarded when compared with the agreement of the common people. ${ }^{23}$ Disregarded means ignored with the agreement of the chiefs class which does not benefit the common, but if the chiefs disagreed along with the agreement of the common, the impact of the chiefs' disagreement is disregarded. ${ }^{24}$

\subsection{Choose the Honest Entourage of Ministers and State Employees Carefully}

"Allah never sends a prophet or appoints a Caliph but he has two groups of entourage: A group that tells and urges him to do good and a group that tells and urges him to do evil. And the one who is truly protected is the one who is protected by Allah, the Mighty and Sublime." ${ }^{25}$ Said Muhammad (pbuh). Al-Bukhari explained the Hadith by saying, " entourage is the group enters to the private place of the president who tells secrets which believed by him in what is told about hidden matters of his people in order to deal with them." ${ }^{26} \mathrm{Lisan}$ al-Arab also stated, "The advisor is the secret keeper and the president helper who advises him in his matters." ${ }^{27}$

Sofyan Al-Thawri said, "Let your advisors be pious, honest and fearful of Allah."28

In accordance with the internal policy of the country, the Caliph called on the Ruler to choose his entourage of ministers carefully, unless they have served unjust previous regimes. The Ruler had to choose new ministers who had not served before and had not wronged anyone. "Your worst ministers will be the men who had been ministers to the despotic rulers before you and who had been a party of atrocities committed by them. Such people should not be taken into your confidence and should not be

\footnotetext{
${ }^{19}$ See Ibn Abi Hadid, Explanation of the Rhetoric Approach (p. 261 / vol. 20).

${ }^{20}$ History of Islam (3/152).

${ }^{21}$ Bin Hamdoun, Atazkara Al-Hamdunia (1/320): Al-Nuwairi, Nihayat al-Arb fi Fnoun al-Adab (6/20).

${ }^{22}$ Khalil, al-Musnad al-Jama'ah, (18/779).

${ }^{23}$ Bin Hamdoun, Atazkara Al-Hamdunia (1/317): Al-Nuwairi, Nihayat al-Arb fi Fnoun al-Adab (6/20).

${ }^{24}$ Mohammed Abdo, Explanation of the Rhetoric Approach (p. 86).

${ }^{25}$ Al-Bukhari, Sahih al-Bukhari, (9/77).

${ }^{26}$ Al-Aini, SharhSahih al-Bari, (24/269).

${ }^{27}$ Ibn Manzur, Lisan al-Arab (13/55).

${ }^{28}$ Ibn Battal, SharhSahih al-Bukhari, (8/272).
} 
trusted because they have aided sinners and have assisted tyrants and cruel rulers. In their stead, you can comfortably find people who are equally wise and learned but who have not developed sinful and criminal mentalities, who have neither helped the tyrants in their tyrannies nor have they assisted them to carry on their sinful deeds. Such persons will prove the least troublesome to you. They will be the most helpful." 29

\subsection{Apply the Principle of Shura}

Shura is one of sharia laws and duties. The ruler must step down unless he consult the scholars and religious people ${ }^{30}$. He must consult with scholars about things they do not know in religious matters, army professionals regarding war issues, best of people regarding interests, and best of writers, ministers and workers regarding the interests and the prosperity of the state. ${ }^{31}$ In addition, Hasan alBasari said, "Allah commanded his prophet for counseling with people, not because he needed their opinions, but because he wanted to teach them that counseling is required and the Islamic nation should follow the prophet by using it." ${ }^{32}$ Sufyan al-Thawri also said, "I have heard that counseling is half of the mind." ${ }^{33}$

Shura is one of the basis of the Islamic political regime which included all Muslim issues. In accordance with this fact, the Islamic State preceded the modern democratic regimes in the need for the community approval to choose their ruler who take care of its issues and interests and manage their affairs, confirming that unanimity is influential and valuable among Muslims. ${ }^{34}$

Therefore, Ali bin Abi Talib commanded Egypt Ruler to consult with the scholars about the State's issues to achieve the principle of shura, "Keep on increasing your conversations with the scholars and discussions with the wise to stabilize the prosperity of the areas under you control, and to continue with that in which your predecessors had established." ${ }^{35}$

\subsection{Adopt the Policy of Separation of Powers}

By looking at the era of Ali bin Abi Talib, we can realize the beginning of separation of powers law and non-interference in the affairs of the rulers by the superpower or majority. This is confirmed by his words, "Establish one chief for every department of work. He should not be incapable of big matters, and a rush of work should not perplex him." ${ }^{36}$

Montesquieu set the separation of powers law $^{37}$ under which the three branches of government (executive, legislative, and judicial) are kept separate and the policy of absolutisms undermined. ${ }^{38}$ However, Ali bin Abi Talib pointed to it without details by commanding the non-interference in the affairs of superpower or the unfair subjection to the opinion of the majority.

\section{Section2: The International Administration in the Era of Ali Bin Abi Talib}

The new covenant included foundations of administrating the states in past and present. It was an administrative constitution for the modern state to organize its administrative and economic affairs based on the legal investment, transparency and the practical economic development based on justice and accountability in addition to the promotion of the principle of social solidarity and justice.

This section includes:

- The economic development.

- Human rights mentioned in the covenant.

\footnotetext{
${ }^{29}$ Bin Hamdoun, Atazkara Al-Hamdunia (1/318): Al-Nuwairi, Nihayat al-Arb fi Fnoun al-Adab (6/22).

${ }^{30}$ Al-Qurtubi, Tafseer al-Qurtubi (4/249).

${ }^{31}$ Zuhaili, Islamic Jurisprudence and Its Evidence (8/6205).

${ }^{32}$ Bin Humaid, Nazrat al-Naeem fi MakaremAkhlaq al-Rasoul al-Kareem (6/2439).

${ }^{33}$ Ibn Battal, SharhSahih al-Bukhari, (8/272).

${ }^{34}$ Al-Nabrawi, History of Islamic Regimes and Civilization (p. 24).

${ }^{35}$ Bin Hamdoun, Atazkara Al-Hamdunia (1/319): Al-Nuwairi, Nihayat al-Arb fi Fnoun al-Adab (6/23).

${ }^{36}$ Bin Hamdoun, Atazkara Al-Hamdunia (1/323): Al-Nuwairi, Nihayat al-Arb fi Fnoun al-Adab (6/23).

${ }^{37}$ Montesquieu, a French philosopher and the founder of separation of powers theory, which is currently adopted by most regimes.

${ }^{38}$ Durant, The Story of Civilization (36/165).
} 
The Administrative Strategy of the Islamic State by the Righteous Caliphs Decrees: Case Study on the Decree of Ali bin Abi Talib to the Ruler of Egypt

\section{First, economic development}

Economic development in Islam is a duty and one of the best worships in which Islamic nation and leaders are close to Allah as much as they reconstruct the world by all means of development under the Islamic rules. These rules are distinguished from other common economic systems. According to the analysis of this study, Islamic economic development is comprehensive and balanced, focusing on the man to be the right successor of Allah in his land. ${ }^{39}$

\subsection{Cultivating the Land Before Collecting Revenue}

"You should keep an eye on the cultivation of the land more than on the collection of revenue because revenue cannot be had without cultivation and whoever asks for revenue without cultivation, ruins the area and brings death to the people. His rule will not last only a moment. If they complain of the heaviness (of the revenue) or of diseases, or dearth of water, or excess of water or of a change in the condition of the land either due to flood or to drought, you should remit the revenue to the extent that you hope will improve their position. The remission granted by you for the removal of distress from them should not be grudged by you, because it is an investment which they will return to you in the shape of the prosperity of your country and the progress of your domain in addition to earning their praise." ${ }^{40}$

The Caliph Ali bin Abi Talib urged to focus on cultivating the land more than collecting the revenue. It is a comprehensive economic development rule indicates that the promotion of state economy is more significant than collecting the taxes since many states collapsed due to large taxes and royalties on the people.

The previous and subsequent regimes increased the taxes and imposed more royalties on people. They chased people on their living, the strong stole the weak and the cleaver cheated the foolish. Therefore, those peoples suffered forms of poverty, humiliation, stagnation, fear and instability because they missed security on their lives and money. ${ }^{41}$

\section{Second: trade organization}

Prophet Muhammad (pbuh) said, "Each man has his own business and each legal selling is accepted." Muslims agreed that selling is allowed because a man needs what others have and they refuse to give without compensation. By legitimizing selling, every man achieves his goals and meets his needs. Humans are civilian in nature and they cannot live without collaboration with others. ${ }^{42}$

The state has the duty to guarantee the rights of the workers, subsidize the unemployed, open new projects for them in order to eliminate unemployment and increase the economic growth rate of the state so the well-being of the citizens will be better. Therefore, the Caliph was careful to organize the trade and guarantee trader and citizen rights fairly. ${ }^{43}$

"Now take some advice about traders and industrialists. Give them good counsel whether they be settled (shop-keepers) or traders or physical laborers because they are sources of profit and the means of the provision of useful articles. They bring them from distant and far-flung areas throughout the land and sea, plains or mountains, from where people cannot come and to where they do not dare to go, for they are peaceful and there is no fear of revolt from them, and they are quite without fear of treason. Look after their affairs by yourself wherever they may be in your area. Know, along with this, that most of them are very narrow-minded, and awfully avaricious. They monopolize goods for profiteering and fix high prices for goods. This is a source of harm to the people and a blot on the officers in charge." ${ }^{44}$

Islam organized the righteous methods to deal with money and regulate financial affairs by prohibiting monopoly. This is permissible in the pre-Islamic and capitalist regimes. The monopolists think that they are intelligent in raising their money, but Islam considered them as big sinners. ${ }^{45}$

\footnotetext{
${ }^{39} \mathrm{Al}-$ Fangri, Islam and the Economic Balance between Individuals and States (p. 64).

${ }^{40}$ Bin Hamdoun, Atazkara Al-Hamdunia (1/322): Al-Nuwairi, Nihayat al-Arb fi Fnoun al-Adab (6/24).

${ }^{41}$ Al-Rahili, The Approach of the Quran to Inviting the Polytheists to Islam (1/326).

${ }^{42}$ Ibn Abi Shaybah, Musannaf Ibn Abi Shaybah (4/554).

${ }^{43}$ Wishah, Human Rights in Islamic State (p.56).

${ }^{44}$ Bin Hamdoun, Atazkara Al-Hamdunia (1/323): Al-Nuwairi, Nihayat al-Arb fi Fnoun al-Adab (6/24).

${ }^{45}$ Awaji, Modern Intellectual Doctrines (2/1312).
} 
BinKhaldoun said, "Controlling the money of people is one of the worst forms of injustice and corruption of the urbanization and state. It means buying what people own in the cheapest prices and then impose the highest prices on goods under duress and force them to buy and sell or the prices may be imposed on delay. ${ }^{46}$

The Caliph was careful to clarify this for the traders through his covenant, he said, "Stop people from monopoly, because the Messenger of Allah (pbuh) has prohibited it. The sale should be smooth, with correct weights and prices, not harmful to either party, the seller or the purchaser; whoever commits monopoly after you prohibit it, give him exemplary but not excessive punishment."47

The Islamic ruling referred to the laws of the price floor ${ }^{48}$, and the price ceiling ${ }^{49}$ to protect the producer and the consumer as the Muslim ruler recommended, "Do no harm to either party, the seller or the purchaser; whoever commits monopoly after you prohibit it, give him exemplary but not excessive punishment." 50

\subsection{Human Rights in the Era of Ali Bin Abi Talib}

The philosophy of Islam and its laws never deviated from values and morals, which adopted a set of rights that included all human beings, without distinction based on color, gender or language. These rights also included the environment in which people deal with are guaranteed and implemented under law and any violation leads to impose sanctions as Allah said in the Holy Quran, " And We have certainly honored the children of Adam and carried them on the land and sea and provided for them of the good things and preferred them over much of what We have created, with [definite] preference." ${ }^{51}$

This fact gives human rights in Islam special characteristics mainly because they are comprehensive, including political, economic, social and intellectual rights. They are also general for all people whether Muslims or non-Muslims without any discrimination based on color, gender and language. They are Irrevocable or unchangeable because they are associated with Allah's teachings. ${ }^{52}$

Muslim Caliphs were keen to apply these legal characteristics in Islam. There was a legal document based on Islamic religious teachings in the time of Ali bin Abi Talib. It contained many orders and the ruler to disseminate justice and guarantee human rights in the Islamic State.

\subsection{The Right to Justice}

Justice is the foundation of ruling which continues with the application of justice. Ruling, even in Islam, could collapse if injustice is increased. IbnTaymiay stated, "In this world, people's affairs are in the right way by applying justice even with committing some sins. However, they are in the wrong way if there is injustice in rights without committing sins."Therefore, it is said, "Allah establish the just state although it is infidel and he does not establish the unjust state even it is Muslim," and it is said, "The world lasts with justice and disbelief and does not last with injustice and Islam.. Justice is the system of everything, the world lasts with the establishment of justice even if its people have nothing for the hereafter, otherwise, it does not establish without justice even if its people have everything for the hereafter. ${ }^{53}$ In light of this, Muhammad (pbuh) said, "the closest and most beloved people to Allah on the Day of Judgment is a just Imam (ruler), and the farthest and the most hated one to Allah is an unjust imam." ${ }^{54}$

Therefore, justice is the basis of ruling and Islamic religion since it is a law, state, religion and world. Justice is a duty on rulers to guarantee all rights for all people, as many verses in the Quran confirmed such as, "Be just; that is nearer to righteousness."

\footnotetext{
46 Ibn Khaldun, The History of Ibn Khaldun (1/357).

${ }^{47}$ Bin Hamdoun, Atazkara Al-Hamdunia (1/323): Al-Nuwairi, Nihayat al-Arb fi Fnoun al-Adab (6/24).

${ }^{48}$ The law which protects the producer from loss by fixing the lowest selling price.

${ }^{49}$ The law which protects the consumer from the impact of high prices and puts a final price of the product.

${ }^{50}$ Bin Hamdoun, Atazkara Al-Hamdunia (1/323): Al-Nuwairi, Nihayat al-Arb fi Fnoun al-Adab (6/24).

${ }^{51}$ surah Al Isra 70 (QS 17: 70).

${ }^{52}$ Sarjani, the Story of Islam, Http://islamstory.com

${ }^{53}$ Wishah, Human Rights in the Islamic State p. 105.

${ }^{54}$ Al-Bayhaqi, Al-Sunan Al-Kubra (Vol.10, p. 88).

${ }^{55}$ Surah Al-Maidah 5 (5:8).
} 
The Caliph recommended the ruler to be just and merciful, " The way most coveted by you should be that which is the most equitable for the right, the most universal by way of justice, and the most comprehensive with regard to the agreement among those under you," 56 "Habituate your heart to mercy for the people and to affection and kindness for them. Do not stand over them like greedy beasts who feel it is enough to devour them, since they are of two kinds, either your brother in religion or one like you in creation." ${ }^{57}$

The Caliph recommended what guarantee rights and equality to achieve the principle of justice, "For the settlement of disputes among people select him who is the most distinguished of your people in your view. The cases (coming before him) should not vex him, disputation should not enrage him, he should not insist on any wrong point, and should not grudge accepting the truth when he perceives it. He should not lean towards greed and should not content himself with a cursory understanding (of a matter) without going thoroughly into it ${ }^{58} \ldots$ The virtuous and the vicious should not be in equal position before you because this means dissuasion of the virtuous from virtue and persuasion of the vicious to vice. Keep everyone in the position which is his." ${ }^{59}$

Moreover, the Caliph confirmed the importance of justice to prevent discontent of citizens, "The most pleasant thing for the rulers is the establishment of justice in their areas and the manifestation of the love of their people." 60

The Caliph asserted on the inviolability of shedding blood without right as Allah said," That was why We wrote for the Children of Israel that who ever killed a soul, except for a soul slain, or for sedition in the earth, it should be considered as though he had killed all mankind; and that who ever saved it should be regarded as though he had saved all mankind. Our Messengers brought them proofs; then many of them thereafter commit excesses in the earth." ${ }^{61}$ The prophet (pbuh) also said, "The demise of the world is inferior to Allah than the kill of a believer without right."

The recommendations of the Caliph were based on the Islamic sharia, which prohibit killing and aggression in any way. It was said that the first thing that Allah will judge on the Day of Resurrection among the slaves is the issue of blood, the Caliph said, "There is nothing worse than shedding blood in the cause of affliction, disappearance of blessings, and transfer of nations. If you think that you strengthen your authority by doing so, then it is not like that, but rather you weaken and execute it completely." ${ }^{\prime 2}$

It was written in the document sent to the Egyptian ruler, "You should avoid shedding blood without justification, because nothing is more inviting of Divine retribution, greater in (evil) consequence, and more effective in the decline of prosperity and cutting short of life than the shedding of blood without justification. On the Day of Judgment Allah the Glorified, would commence giving His judgment among the people with the cases of bloodshed committed by them.

Therefore, do not strengthen your authority by shedding prohibited blood because this will weaken and lower the authority, moreover destroy it and shift it. You cannot offer any excuse before Allah or before me for wilful killing because there must be the question or revenge in it. If you are involved in it by error and you exceed in the use of your whip or sword or hand in inflicting punishment, as sometimes even a blow by the fist or a smaller stroke causes death, then the haughtiness of your authority should not prevent you from paying the blood price to the successors of the killed person." 33

\subsection{The Right to Social Security}

Social security means that every individual shall be under the protection and care of the state which represent the whole community. ${ }^{64}$ It means the obligation of the Islamic State towards all its residents,

\footnotetext{
${ }^{56}$ Bin Hamdoun, Atazkara Al-Hamdunia (1/317): Al-Nuwairi, Nihayat al-Arb fi Fnoun al-Adab (6/24).

${ }^{57}$ Bin Hamdoun, Atazkara Al-Hamdunia (1/316).

${ }^{58}$ Bin Hamdoun, Atazkara Al-Hamdunia (1/321): Al-Nuwairi, Nihayat al-Arb fi Fnoun al-Adab (6/24).

${ }^{59}$ Bin Hamdoun, Atazkara Al-Hamdunia (1/318)

${ }^{60}$ Ibid (1/318).

${ }^{61}$ Surah Al-Maidah 5 (5:32).

${ }^{62}$ Ibn Majah, Sunan Ibn Majah (2/874).

${ }^{63}$ Bin Hamdoun, Atazkara Al-Hamdunia (1/327): Al-Nuwairi, Nihayat al-Arb fi Fnoun al-Adab (6/20).

${ }^{64}$ Zuhaili, Islamic Jurisprudence and Its Evidence (7/5007).
} 
regardless of their religion or nationality, to provide assistance to the needy in cases of disease, disability or old age, when they have no income or sufficient financial resource and without requesting advance subscription. ${ }^{65}$

Therefore, when the Caliph took over the caliphate, he assured, " Oh Allah, you know that I do not want the leadership, supreme power or authority, yet I want toset your boundaries, perform your legitimacy, and put things in the right place, give rights to its people, follow the sunnah of your prophet and guide the lost to the lights of your guidance." 66

The Caliph of Muslims recommended the Ruler to apply the principle of social solidarity and security, taking into consideration social classes' distribution as he wrote," Know that the people consist of classes who prosper only with the help of one another, and they are not independent of one another. Among them are the army of Allah, then the secretarial workers of the common people and the chiefs, then the dispensers of justice, then those engaged in law and order, then the payers of head tax (jizyah) and land tax (kharaj) from the protected non-Muslims and the common Muslims, then there are the traders and the men of industry and then the lowest class of the needy and the destitute. Allah has fixed the share of every one of them and laid down His precepts about the limits of each in His Book (Quran) and the sunnah of His Prophet by way of a settlement which is preserved with us." ${ }^{167}$

In addition, he was very keen on the lowest class of needy and destitute, " Then is the lowest class of the needy and the destitute support of and help for whom is an obligation, and everyone of them has (a share in) livelihood." ${ }^{68} \mathrm{He}$ recommended helping this class in order to achieve the social solidarity, "(Fear) Allah and keep Allah in view in respect of the lowest class, consisting of those who have few means: the poor, the destitute, the penniless and the disabled; because in this class are both the selfcontained needy and those who beg. Take care for the sake of Allah of His obligations towards them for which $\mathrm{He}$ has made you responsible. Fix for them a share from the public funds and a share from the crops of lands taken over as booty for Islam in every area, because in it the remote ones have the same shares as the near ones. All these people are those whose rights have been placed in your charge. Therefore, a luxurious life should not keep you away from them youcannot be excused for ignoring small matters because you were deciding big problems. Consequently, do not be unmindful of them, nor turn your face from them out of vanity. Take care of the affairs of those of them who do not approach you among those who are looked at with contempt and whom people regard as low." ${ }^{69}$

The Caliph recommended to follow the conditions of the poor, understand their pride and be fair with them, as well as taking care of orphans and newborn, "Appoint for them some trusted people who are God-fearing and humble. They should inform you of these people's conditions. Then deal with them with a sense of responsibility to Allah on the day you will meet Him, because these people are the most deserving of equitable treatment, while for others also you should fulfil their rights to render account to Allah.Take care of the orphans and the aged who have no means (for livelihood) nor are they ready for begging. This is heavy on the officers; in fact, every right is heavy. Allah lightens it for those who seek the next world and so they endure (hardships) upon themselves and trust on the truthfulness of Allah's promise to them." ${ }^{70}$

Moreover, the Caliph ordered to devote time for needy people of poor and patients and anyone needs something from the ruler, "And fix a time for complainants wherein you make yourself free for them, and sit for them in common audience and feel humble therein for the sake of Allah who created you. (On that occasion) you should keep away your army and your assistants such as the guards and the police so that anyone who like to speak may speak to you without fear. I have heard the Messenger of Allah (S) say in more than one place, "The people among whom the right of the weak is not secured from the strong without fear will never achieve purity." Tolerate their awkwardness and inability to speak. Keep away from you narrowness and haughtiness; Allah would, on this account, spread over

\footnotetext{
${ }^{65} \mathrm{Al}-$ Fangri, Islam and the Economic Balance between Individuals and States (p. 71).

${ }^{66}$ Ibn Abi al-Hadid, SharhNahjulBalaghah (20/299).

${ }^{67}$ Bin Hamdoun, Atazkara Al-Hamdunia (1/319): Al-Nuwairi, Nihayat al-Arb fi Fnoun al-Adab (6/27).

${ }^{68}$ Bin Hamdoun, Atazkara Al-Hamdunia (1/320): Al-Nuwairi, Nihayat al-Arb fi Fnoun al-Adab (6/21).

${ }^{69}$ Bin Hamdoun, Atazkara Al-Hamdunia (1/323).

${ }^{70}$ Ibid (1/323).
} 
The Administrative Strategy of the Islamic State by the Righteous Caliphs Decrees: Case Study on the Decree of Ali bin Abi Talib to the Ruler of Egypt

you the skirts of His mercy and assign the reward of His obedience for you. Whatever you give, give it joyfully." ${ }^{71}$

\section{RESUltS}

- The strategy of Islamic ruling comprises all aspects of international construction. This is clear in the era of Ali bin Abi Talib through what the covenant included of economic, social, political, administrative and legal recommendations.

- The Islamic State preceded the modern regimes in the field of human rights, "the way most coveted by you should be that which is the most equitable for the right, the most universal by way of justice, and the most comprehensive with regard to the agreement among those under you."

- The Islamic State in the era of Ali bin Abi Talib used the principle of shura in all its decisions "Keep on increasing your conversations with the scholars and discussions with the wise to stabilize the prosperity of the areas under your control, and to continue with that in which your predecessors had established."

- Internal policy characterized by kindness, compassion and good treatment, "the manifestation of the love of their people in which their love manifests itself only when their hearts are clean."

- The covenant pointed out the principle of separation of powers, "Establish one chief for every department of work. He should not be incapable of big matters, and a rush of work should not perplex him."

- The State exerted great efforts to achieve economic development and focused on the production rather than collecting revenues, "you should also keep an eye on the cultivation of the land more than on the collection of revenue."

- The Islamic State organized trading operations and prohibited monopoly, "Stop people from monopoly, because the Messenger of Allah (SWT) has prohibited it."

- The Islamic state preserved the rights of needy and achieved the social solidarity, "Fear Allah and keep Allah in view in respect of the lowest class, consisting of those who have few means: the poor, the destitute, the penniless and the disabled."

\section{REFERENCES}

[1] The Holy Quran Abu Jaafar al-Tabari, Muhammad binJarirbinYazidibnKathirbinGhalib al-Amali, Abu Jaafar al-Tabari (died in $310 \mathrm{AH}$ ).

[2] Tafseer al-Tabari, Dar Hajar, (1 ${ }^{\text {st }}$ ed.), 1422 AH. Baha'a al-Din al-Baghdadi, Muhammad bin al-Hasan bin Muhammad bin Ali binHamdun, Abu al-Ma'ali, Baha'a al-Din al-Baghdadi (died in $562 \mathrm{AH}$ )

[3] Atazkara Al-Hamdunia, Dar Sader, 1417 AH, (1 ${ }^{\text {st }}$ ed.), Beirut. Bin Abi Hadid, Abdul Hameed binHebat Allah bin Muhammad bin al-Husaynbin Abi al-Hadid, Abu Hamid, Izz al-Din (died in 656 AH)

[4] SharhNahjulBalaghah, Dar Ihya'a al-kutub al-Arabia Ibn Kathir, Abu al-Fida'aIsma'il ibn Omar bin Kathir al-Qurashi al-Basri and then al-Dimashqi, (died in $774 \mathrm{AH}$ ).

[5] al-BidayahwlNihayah, Dar Hajar, $1^{\text {st }}$ ed, 2003. Ibn Taymiyah, Taqi al-Din Abu al-Abbas Ahmad bin Abd al-Halim bin Abd al-Salam bin Abd-Allah bin Abi al-Qasim bin Muhammad Ibn Taymiyah alHaraniHanbali al-Dimashqi (died in $728 \mathrm{AH})$.

[6] Great Fatwas, Ibn Taymiyah, Dar al-Kutub al-Elmiah, 1408 AH. Al-Dhahabi, Shams al-Din Abu Abdullah Muhammad bin Ahmed bin Othman Ibn Qaimaz al-Dahabi (died in 748 AH).

[7] History of Islam and the Deaths of Celebrities and Media, Dar al-Kitab al-Arabi, 1413 AH, Beirut. AlBukhari, Muhammad bin Ismail Abu Abdullah al-Bukhari al-Jafi

[8] Al-Jami' al-Musnad al-Sahih al-Mukhtasar of the Messenger of Allaah (pbuh), his Sunnah and his days = Sahih al-Bukhari, Dar Tawq al-Najat, $1^{\text {st }}$ ed, 1422 AH. Al-Aini, Abu Muhammad Mahmoud bin Ahmed bin Musa bin Ahmed bin Hussein al-Ghaitabial-Hanafi Badr al-Din al-Aini (Died in 855 AH).

[9] Omdat al-Qari, SharhSahih Al-Bukhari, Dar Ihya'a al-Turath al-Arabi, Beirut. Ibn Mazour, Muhammad bin Makram bin Ali, Abu al-Fadl, Jamal al-Din Ibn Mazour al-Ansari al-Ruwaifial-Afriqi (died in 711 $\mathrm{AH})$.

\footnotetext{
${ }^{71}$ Ibid (1/324).
} 
The Administrative Strategy of the Islamic State by the Righteous Caliphs Decrees: Case Study on the Decree of Ali bin Abi Talib to the Ruler of Egypt

[10] Lisan al-Arab, Dar Sader, $3^{\text {rd }}$ ed, 1414 AH, Beirut. Ibn Battal, Ibn Battal Abu Hassan Ali bin Khalaf bin Abdal-Malik (died in $449 \mathrm{AH}$ ).

[11] SharhSahih al-Bukhari le Ibn Battal, Dar al-Rushed, 1423 AH, Saudi Arabia. Al-Qurtubi, Abu Abdullah Muhammad ibn Ahmad ibn Abi Bakr ibn Farah al-Ansari al-Khazraji Shams al-Din al-Qurtubi (died in $671 \mathrm{AH})$.

[12] Al-Jami' le Ahkam al-Quran= Tafseer al-Qurtubi, Dar al-Kutub al-Asriah, Cairo. Al-Bayhaqi, Ahmad bin al-Husayn bin Ali bin Musa al-Khasrojrdi al-Kharasani, Abu Bakr al-Buhaqi (died in $458 \mathrm{AH}$ ).

[13] Al-Sunan Al-Kubra, Dar al-Kutub al-Elmiah, Beirut. Ibn Majah, ibn Majah Abu Abdullah Muhammad ibn Yazid al-Quzwini, Majah is the name of his father Yazid (died in $273 \mathrm{AH}$ ).

[14] Sunan Ibn Majah, Dar al-Kutub al-Arabia, Beirut. Bin Abi Shaybah, Abu Bakr bin Abi Shaybah, Abdullah bin Muhammad bin Ibrahim bin Othman bin Khawasti al-Absi (died in $235 \mathrm{AH}$ ).

[15] AL-Kitab al-Musanaf fi al-Ahadithwl Athar, Al-Rushed Library, Riyadh. Al-Nuwairi, Ahmad ibn Abd alWahhabbin Muhammad bin Abd al-Daem al-Qurashi al-Taymi al-Bakri, Shihab al-Din al-Nuwairi (died in $733 \mathrm{AH})$.

[16] Nihayat al-Arb fi Fnoun al-Adab, Dar al-KutubwlWathaeq al-Qawmiya, 1423 AH, Cairo.

[17] Wishah, Ghassan, Human Rights in the Islamic State, PhD thesis, Al-Jinan University, Lebanon, 2012.

[18] Muhammad, Abdu, SharhNahjul al-Balagha, Vol.1, Dar al-Maarifah, Beirut.

[19] Al-Zuhaili, Wahba, Islamic jurisprudence and its evidence, Dar al-Fikr, Damascus.

[20] Saleh bin Abdullah, et al., Nazrat al-Naeem fi MakaremAkhlaq al-Rasoul al-Kareem, Dar Al-Wasila for publication, Jeddah.

[21] Al-Fangri, Muhammad, Islam and the Economic Balance between Individuals and States, Ministry of Awqaf, Jeddah.

[22] Al-Zuhaili, Hamouda, the Approach of the Holy Quran in Inviting Disbelievers to Islam, Islamic University, $1424 \mathrm{AH}$, Medina.

[23] Awaji, Ghaleb Bin Ali, Modern Intellectual Schools, and their Role in Societies and the Role of Muslim of them, al-Maktabah al-Asriyah, 1427 AH, Jeddah.

[24] Khalil, Mahmoud, Al-Musnad Al-Jami', Dar al-Jalil, 1993.

[25] Ghanem, Jawad, et al., the Old Right Human Rights in Islamic Culture, Cairo Center, 2000.

[26] Al-Fikiki, Tawfiq, TheRuler and the People, The Library of Ma'arif, 1962, Iraq.

[27] Shaltout, Mahmoud, Islam Doctrine and Sharia, Dar Al-Shorouk, 2001, Cairo.

[28] Durant, William James Durant, The Story of Civilization, Dar al-Jil, 1988, Beirut, Lebanon.

\section{AUTHORS' BIOGRAPHY}

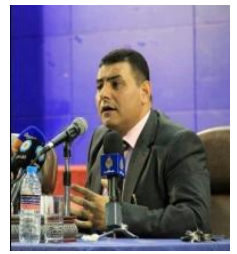

Dr. Ghassan Mahmoud Weshah is a Palestinian historian. Currently working as Head of History and Archeology Department at the Islamic University of Gaza. Member of the International Federation of Historians. A member of the Union of Arab Historians in Cairo and a member of the Union of Arab Historians in Iraq. Also Participated in many of scientific conferences.

Citation: Dr. Ghassan Mahmoud Wishah. "The Administrative Strategy of the Islamic State by the Righteous Caliphs Decrees: Case Study on the Decree of Ali bin Abi Talib to the Ruler of Egypt". International Journal of History and Cultural Studies (IJHCS). vol 5, no. 1, 2018, pp. 25-35. doi: DOI: http://dx.doi.org/ 10.20431/2454-7654.0501003.

Copyright: (c) 2019 Authors. This is an open-access article distributed under the terms of the Creative Commons Attribution License, which permits unrestricted use, distribution, and reproduction in any medium, provided the original author and source are credited. 